\title{
Applied Load and Calibration of the Hardness Tester
}

Jozef Petrik, Marek Solc, Vojtech Miklos

Department of Integrated Management, Faculty of Metallurgy, Technical University of Košice, Letná 9, 04200 Košice, Slovakia,jozef.petrik@tuke.sk

Introduction into problems - It is expected that the measured value of the hardness will not be dependent on the applied test load and operators carried out the measurement. The Vickers hardness tester was calibrated by three operators using loads between 49.03 and $980.7 \mathrm{~N}$ and one CRM (standard) for a full load range. The uncertainty of obtained results was calculated in accord with standard ISO 6507-2 and tolerances analyze method. The capability of the calibration was evaluated by GRR method of the Measurement systems analysis (MSA). The method of total dispersion zone was used for estimation the impact of the variability between operators at particular loads on the measured value of the hardness. The influence of the load on the hardness expressed by Meyer's index " $n$ " excluded ISE (indentation size effect). The influence of operators on the resultant hardness is weak, and the impact of applied load is ambiguous. The values of uncertainty calculated in accordance with the standard and by tolerance analysis are comparable.

Keywords: Vickers hardness test, calibration, uncertainty, capability

\section{Acknowledgements}

This paper was created with the support of the Ministry of Education, Science, Research and Sport of the Slovak Republic KEGA TnUAD009/2011 Creative Laboratory Education at Technical Faculties (CRELABTE).

\section{References}

[1] ISO 10 012:2003 Measurement management systems - Requirements for measurement processes and measuring equipment.

[2] VASKOVÁ, I., ŠEBEK, P., MULI, I. (2013): Hardness of Ductile Cast Iron Castings and its Control in Praxis. In: Manufacturing Technology Journal, Vol 13, No. 1, pp. 120-122, Czech republic.

[3] SUCHÁNEK, D., DUŠÁK, K. (2011): The impact of the cast-iron semi-finished product hardness on the surface quality after the machining. In: Manufacturing Technology Journal, Vol. 11, No. 11, pp. 66-70, Czech republic.

[4] TIllova, E., CHAlupovÁ, M., HuRTAlOVA, L., ĎURINÍKOVÁ, E. (2011): Quality control of microstructure in recycled Al-Si cast alloys. In: Manufacturing Technology Journal, Vol. 11, No. 11, pp. 70-76, Czech republic.

[5] ISO/IEC 17 025:2005 General requirements for the competence of testing and calibration laboratories.

[6] STN EN ISO 6507-2:2005. Metallic materials. Vickers hardness test. Part 2: Verification and calibration of testing machines.

[7] Measurement systems analysis - MSA (2010), pp. 102-120, Chrysler Group LLC, Ford Motor Company, General Motors Corporation.

[8] TUREKOVÁ, I., TURŇOVÁ, Z., VEKONY, P., PASTIER, M. (2013). Study of polymeric materials burning. In: Applied Mechanics and Materials, Vol. 295-298, No. 1, pp. 471-474, Germany.

[9] PETRÍK J. et al. (2008). The evaluation of the hardness tester quality. In: Acta Metallurgica Slovaca, Vol. 14, No. 3, pp. $405-413$. Slovakia.

[10] STN EN ISO 6507-1:2005 Metallic materials. Vickers hardness test. Part 1: Test method.

[11] ADAMS, T. M. (2002). G104 - A2LA Guide for Estimation of Measurement Uncertainty In Testing.

[12] EA-10/16 EA (2004). Guidelines on the Estimation of Uncertainty in Hardness Measurements. Annex Guideline to the evaluation of the uncertainty of the Brinell and the Vickers measuring method.

[13] TPM 0051-93 (1993) Stanovenie neistôt pri meraniach.

[14] ISO/TS 16949:2009 Quality management systems. Particular requirements for the application of ISO 9001:2008 for automotive production and relevant service part organization. 
[15] QIANG, X., MAJLINGOVÁ, A., ZACHAR, M., CONG, J., ZANG, J. (2012). Correlation analysis of cone calorimetry test data assessment of the procedure with tests of different polymers. In: Journal of Thermal Analysis and Calorimetry, Vol. 110, No. 1, pp. 65-70, Netherlands.

[16] PRÍSTAVKA, M., HRUBEC, J., BUJNA, M., KOTOROVÁ, M. (2011). Quality control in production processes. In: Toyotarity. Control in Organizations, pp. 121-129. Publisher Yurii V. Makovetsky, Dnipropetrovsk, Ukraine.

[17] LESTYÁNSKA - ŠKŮRKOVÁ, K (2010). Determining of the total dispersion zone for measuring equipment profiloprojector Sm. In: Toyotarity. Structure of control elements importance, pp. 40-47. Publisher Yurii V. Makovetsky, Dnipropetrovsk, Ukraine.

[18] SANGWAL, K., SUROWSKA, B., BŁAZIAK, P. (2002). Analysis of the indentation size in the Microhardness measurement of some cobalt-based alloys, In: Materials Chemistry and Physics, Vol. 77, No. 2., pp. 511-520, Netherlands.

[19] SANGWAL, K. (2000). On the reverse indentation size effect and microhardness measurement of solids, In: Materials Chemistry and Physics, Vol. 63, No. 2, pp. 145-152, Netherlands.

[20] PETRÍK, J., PALFY, P. (2011). The influence of the load on the hardness. In: Metrology and measurement systems, Vol. 18, No. 2, pp. 223-234, Poland.

[21] PLURA, J., KLAPUT, P. (2012): Influence of the interaction between parts and appraisers on the results of repeatability and reproducibility analysis. In: Kvalita Inovácia Prosperita / Quality Innovation Prosperity, Vol. 16, No. 1, pp. 25-36, Slovakia. 